\title{
Sanitary Facilities Location in Nigeria: Implications for population Health
}

\author{
Eno Eyak James $^{1} \quad$ Aniedi Udo Essien ${ }^{2 *} \quad$ Eyo Effiong Etim ${ }^{1}$ \\ 1.Department of Urban and Regional Planning, University of Uyo, Uyo, Nigeria. \\ 2.Department of Geography, University of Uyo, Uyo, Nigeria
}

\begin{abstract}
The study examined the location of sanitary facilities particularly, the septic tank and borehole water in a typical Nigerian urban center. Field measurements were utilized to generate location data on the distance between septic tank and borehole water on twenty-two sampled points across eleven residential zones in Eket LGA of AKS. Water samples from the boreholes were analysed for physico-chemical and bacteriological properties. The chisquare test of goodness of fit was applied on the location data to examine their level of conformity with WHO baseline data; while the regression analysis was conducted to examine the effect of location of septic tanks on the quality of the borehole water. Findings showed massive non-conformity with WHO standards for minimum allowable distance between septic tank and borehole water points. Though no significant relationship was found between septic tank location and the physico-chemical properties of borehole water, the study found significant effect of location on the bacteriological load of borehole water in the area, as it degrades the quality of borehole water and also threatens population health. Intensive awareness campaign against improper location of sanitary facilities (septic tanks) alongside strict enforcement of town planning laws could go a long way in mitigating the situation.
\end{abstract}

Keywords: Sanitary facilities: location; septic tank; borehole water; Nigeria; Population

Health.

DOI: $10.7176 / \mathrm{JRDM} / 54-06$

Publication date: April $30^{\text {th }} 2019$

\section{INTRODUCTION}

Improvement on access to safe water and sanitation facilities are among the core developmental issues facing the developing nations in the world today. The global mandate on water and sanitation are well articulated in the UN sustainable development goal (SDG) number six as a demonstration of global collaboration to address the problem of sanitation.

In Nigeria, whereas, access to water and sanitary facilities have significantly improved through the proliferation of borehole water and septic tanks construction (Abubakar, 2017), the issue of location of these facilities in terms of their conformity with laid down standards has been quite challenging. As quest for socioeconomic opportunity drives population towards an already congested urban center, the Nigeria urban spaces have become blighted with wanton location of sanitary facilities within the neighborhoods (Abubakar, 2017).

In Nigeria urban centers, private boreholes are the main source of domestic and drinking water supply while the septic tanks serve as the major sewage disposal facility. As Ochuko and Thaddeus (2013) rightly noted, the underground septic tank system has been widely utilized in Nigeria living spaces to link old pit latrines and flush toilets as against an old practice of direct discharge of sewage into open drains and surface water courses. However, there is an ongoing debate on the suitability of on-site sanitary facilities such as the septic tank in a densely populated urban center (Kananga, 2003; Ladan, 2014 ;). The opponents of septic tank utilization as a sanitary facility argue that septic tank if poorly designed, ill-maintained and inappropriately located are likely to discharge pollutants into adjacent aquifer thereby threatening the quality and safety of groundwater consumption in those areas (Kawanga, 2003; WHO, 2006; Ochuko and Thaddeus, 2013; Victoria and Ismail, 2011).

A number of studies have attempted to link the depletion in groundwater quality to proximity to septic tank within residential neighborhoods. For instance, Igbinovia, Agwu and Atuanga (2016) concluded that poor management and location of septic tank were injurious to the environment as pathogenic bacteria isolate from septic tanks when released to the environment constitute potential source of epidemic and health concerns. Similarly, Oluwasola, Okunade and Adesina (2017) identified distance to septic tanks location as a significant factor in terms of bacterial pollution of well water in Ado Ekiti, Nigeria. In Lusaka, Zambia, Banda, Mbewe, Nzala and Halwindi (2014) thoroughly documented the level of violation of institutional provisions in the location of boreholes and septic tanks and the attendant repercussions. Though the study failed to establish a direct link between distance from borehole to septic tank and groundwater quality, it was significantly confirmed that alignment of boreholes with septic tank was a major source of groundwater contamination in the area. Elsewhere in Nigeria, findings have shown that improper location of sanitary facilities such as pit latrines, privies, cesspool water closet and septic tanks without compliance with standards can be hazardous to groundwater resource as well as compromise the quality of the urban Environment (Akoteyon, 2015; Odey, Zifi, 
lkhumhen, Kalakodo, Eniang and Giwa, 2016; Arwenyo, Wassawa, Nyeko and Kasozi, 2017).

The world health organization (2006) and the Nigeria Federal Ministry of Environment have stipulated 18 meters as the threshold limits within which the location of sanitary facilities relative to borehole points is permissible. However, the extent to which households and property developers comply with this regulation and the concomitant effect of non-compliance has always been an issue of research.

Eket LGA where the present study is based, is one of the fastest growing urban centers in AkwaIbom State, Nigeria. Eket LGA has a long history of oil and gas exploitation within the continental shelf of its coastal environment. With an extended shoreline/estuary that has attracted massive tourism, the town has been reckoned with rapid population growth (Etim 2016). The attendant challenge of a rapid urbanization in Eket town has been witnessed in the area of poor development control. The location of facilities especially the septic tank and borehole water points within the shrinking residential areas have been wanton and threaten both the aesthetic and health of the environment. There has been little empirical effort by previous researchers to examine the implications of the wanton location of sanitary facilities specifically the septic tank in this area. This paper seeks to contribute knowledge in this regard by assessing the status of compliance of septic tank location with the WHO standard and also relate findings with the quality of borehole water as well as its health implications. Inferences drawn from the observation would help accelerate effort towards improvement in water, sanitation and health standards not only in the study area, but in urban Nigeria in general.

\section{MATERIAL AND METHOD}

The study was designed as a cross-sectional research utilizing both observational and experimental approaches. A population of 116 septic tanks spread across 11 residential zones in the study area was listed. A sample of 22 septic tanks ( 2 from each zone) representing 18.9 percent of total number of septic tanks in the area was investigated in terms of their relative location to the nearest borehole water points.

A baseline measure of 18 meters being the WHO allowable distance between borehole water points and a septic tank was used to assess the appropriateness of septic tanks distribution in the area after field measurements (using tape) of distance between each sample septic tank and the nearest borehole water point was taken. The affected boreholes were geo-referenced using the GPS and coded accordingly for clear identification. Water samples collected from the boreholes were analysed in the AkwaIbom State Ministry of Environment Laboratory Uyo, Nigeria using standard methods. The analysis was done to examine the level of pollution arising possibly from infiltration of pollutants from adjacent septic tank and the likely health implications of the phenomenon.

Specifically, the water samples were tested for bacteriological load such as total viable plate count, total coliform and faecal coliform bacteria. Physical properties such as electrical conductivity, $\mathrm{PH}$, total dissolved solid (TDS) and temperature were analysed using potable meters. Chemical properties such as salinity, chloride, calcium, alkalinity and total hardness were determined using titrimetric method Sulphate, nitrate were determined using spectrophotometer, while magnesium were determined using an atomic absorption spectrophotometer.

The pearson correlation and the standard regression techniques were applied to examine the relationship between septic tanks location and the quality of adjacent borehole water while the chi-square test of goodness of fit was utilized to test for difference between the WHO baseline data and the observed distance between septic tank and borehole in the study area.

\section{RESULTS}

The results of the analysis alongside inferences drawn and relevant discussion are presented as follows:

\subsection{Location of Septic Tank in the Study Area}

The main thrust of this paper has been to examine the level of conformity to the WHO standards in the location of septic tank in relation to borehole water in the study area. The minimum allowable distance between the septic tank and borehole water according to WHO standard is 18 meters (WHO, 2016). This is to reduce the risk of the potential source of contamination from the septic tank. It is a known fact that septic waste water discharge to the sub surface soil infiltrate vertically through the unsaturated zone and into groundwater (lunge 2011) essentially therefore, the regulation on siting of septic tanks and borehole water is one institutionalized steps towards the preservation of groundwater quality. Data in Tables 1 and 2 shows the observable distance between septic tank locations and borehole water points in the study area as well as the descriptive statistic and chi-square result emanating from the data analyses. 
Table 1: Distance between septic tank and borehole water points in the study area(n=22)

\begin{tabular}{|c|c|c|c|c|c|c|}
\hline Coordin & $\begin{array}{l}\text { Easting } \\
\text { Northing }\end{array}$ & $\begin{array}{c}\text { Sample } \\
\text { Point } \\
\text { Code }\end{array}$ & $\begin{array}{c}\text { Observed } \\
\text { Distance } \\
\text { Between Septic } \\
\text { Tank and } \\
\text { Borehole Water } \\
\text { (in meters) } \\
\end{array}$ & $\begin{array}{c}\text { Expected } \\
\text { Distance between } \\
\text { Septic and } \\
\text { Borehole Water } \\
\text { (WHO standard) } \\
\text { in meters } \\
\end{array}$ & $\begin{array}{l}\text { Differerr) } \\
\text { (in met }\end{array}$ & Remarks \\
\hline 379412 & 519959 & 1 & 7 & 18 & -11 & $\begin{array}{l}\text { Below WHO } \\
\text { Expectation }\end{array}$ \\
\hline 379911 & 520013 & 2 & 11 & 18 & -7 & Below WHO Standard \\
\hline 379830 & 518114 & 3 & 19 & 18 & +1 & Above WHO expectation \\
\hline 379529 & 517932 & 4 & 10 & 18 & -8 & Below WHO expectation \\
\hline 378788 & 518640 & 5 & 13 & 18 & -5 & Below WHO expectation \\
\hline 378617 & 518550 & 6 & 11 & 18 & -7 & Below WHO expectation \\
\hline 378254 & 517953 & 7 & 8 & 18 & -10 & Below WHO expectation \\
\hline 378382 & 517264 & 8 & 20 & 18 & +2 & Above WHO expectation \\
\hline 378752 & 517059 & 9 & 8 & 18 & -10 & Below WHO expectation \\
\hline 381243 & 514745 & 10 & 15 & 18 & -3 & Below WHO expectation \\
\hline 381030 & 515046 & 11 & 12 & 18 & -6 & Below WHO expectation \\
\hline 379993 & 513747 & 12 & 21 & 18 & +3 & Above WHO expectation \\
\hline 383419 & 516967 & 13 & 20 & 18 & +2 & Above WHO expectation \\
\hline 383274 & 516850 & 14 & 18 & 18 & 0 & No difference \\
\hline 383482 & 516368 & 15 & 21 & 18 & +3 & Above WHO expectation \\
\hline 383273 & 516533 & 16 & 17 & 18 & -1 & Below WHO expectation \\
\hline 382971 & 515267 & 17 & 20 & 18 & +2 & Above WHO expectation \\
\hline 384258 & 513528 & 18 & 19 & 18 & +1 & Above WHO expectation \\
\hline 386097 & 512584 & 19 & 10 & 18 & -8 & Below WHO expectation \\
\hline 386247 & 512325 & 20 & 12 & 18 & -6 & Below WHO expectation \\
\hline 383732 & 509583 & 21 & 23 & 18 & +5 & Above WHO expectation \\
\hline 384175 & 509692 & 22 & 16 & 18 & -2 & below WHO expectation \\
\hline
\end{tabular}

Source: Data Analysis by Authors 
Table 2: Descriptive Statistics for Distance (in meter) between Septic Tank and Borehole Water in the Study Area

\begin{tabular}{cccccc}
\hline Variable & N & Minimum & Maximum & Mean & Std. Deviation \\
\hline $\begin{array}{c}\text { Distance } \\
\text { Valid N (list wise }\end{array}$ & 22 & 7.00 & 23.00 & 15.04 & 4.99 \\
\hline Sour & & & & \\
\hline
\end{tabular}

Source: Data Analysis by Authors

Table 1 indicates that of the 22 sampled points in the study area, 14 representing 63.6 percent had their septic tank and borehole water located at distance less than 18 meters thereby violating the approved WHO and municipal requirement for the location of sanitary facilities. As data in table 2 indicate, the minimum observed distance between the septic tank and borehole water was 7 meters; while the maximum was 23 meters. However, the mean distance obtained (15.04 metres) reveal that majority of septic tanks in the study area are located in close proximity to Borehole water points. The Standard deviation of 4.99 meters shows that distance between septic tank and borehole water points vary significantly from the mean distance of 15.04 meters across different points to as low as 7 meters which is 8 meters less than the mean distance.

The chi-square analysis tested the goodness of fit between observed distance of septic tank to borehole water and the WHO expected values. At the $95 \%$ probability level $(=\mathbf{0 . 0 5})$ and 21 degrees of freedom, it was observed that the calculated value of chi-square $\left(\boldsymbol{x}_{\boldsymbol{t}}=\mathbf{3 6 . 6 7}\right)$ was by far greater than the table value of chi-square $\left(\boldsymbol{x}^{2}\right)$ implying a significant difference between the observed and expected distance. The rejection of the null hypothesis of "no significant difference between the observed and expected distance further affirm the status of non-conformity to locational standard by property owners in the study area.

\subsection{Quality of Borehole Water in the Study Area}

The results of physico-chemical analyses conducted on the water samples collected from the sampled borehole water in the study area are shown in Table 3. Specifically, Table 3 contains the descriptive statistics of physicochemical properties of the water sample in relation to the WHO standards. Also, the microbial analysis indicating the general pollution status of each water sample is displayed in Table 4.

TABLE 3: Descriptive Statistics of Borehole Water Quality (Physiochemical Parameter)

\begin{tabular}{cccccc}
\hline Parameter & Min. & Max. & $(\overline{\mathbf{x}})$ Mean & Std. Dev. & WHO Standard \\
\hline Colour & 5.00 & 20.00 & 6.35 & 3.46 & 15.00 \\
& & & & & $27-28$ \\
Temperature & 26.10 & 27.80 & 26.79 & 0.44 & 5.00 \\
Turbidity & 0.24 & 0.93 & 0.47 & 0.18 & 6.00
\end{tabular}

\begin{tabular}{|c|c|c|c|c|c|}
\hline $\mathrm{PH}$ & 5.38 & 7.65 & 6.70 & 0.52 & $6.5-8.5$ \\
\hline $\begin{array}{l}\text { Electrical Conductivity } \\
\text { (EC) }\end{array}$ & 27.19 & 87.30 & 61.40 & 20.38 & 1000.00 \\
\hline $\begin{array}{l}\text { Total dissolved solids } \\
\text { (TDS) }\end{array}$ & 14.15 & 49.20 & 31.68 & 10.45 & 500 \\
\hline $\mathrm{Na}^{+}$ & 1.20 & 3.40 & 2.48 & 0.49 & 200 \\
\hline $\mathrm{K}$ & 0.20 & 1.20 & 0.54 & 0.29 & 150 \\
\hline Chloride & 7.40 & 8.93 & 8.14 & 0.42 & 250 \\
\hline $\mathrm{NO}_{3}^{-}$ & 0.01 & 0.36 & 0.08 & 0.06 & 10 \\
\hline $\mathrm{SO}_{4}^{-}$ & 0.30 & 2.30 & 1.76 & 0.41 & 1.5 \\
\hline Alkalinity & 1.00 & 7.90 & 1.99 & 0.01 & 200 \\
\hline Total Hardness (TH) & 15.68 & 39.60 & 25.04 & 6.21 & 100 \\
\hline Calcium & 13.15 & 35.06 & 22.77 & 5.91 & 200 \\
\hline Magnesium & 1.10 & 4.54 & 2.31 & 0.67 & 150 \\
\hline
\end{tabular}

N/B: all units are in $\mathbf{m g} /{ }^{\mathrm{L}-1}$ except for PH, Turbidity and Electrical Conductivity $\left(\mathrm{u}^{\mathrm{s}} \mathrm{cm}^{-1}\right)$

Source: Authors' Analyses

The result of physico-chemical properties of borehole water in the study area indicates a high variability in water colour; large homogeneity in temperature and a $\mathrm{PH}$ tilted towards acidity. Other parameters indicated that Turbidity ranged between 0.24 and $0.93 \mathrm{FTU}$, while the mean values for TDS, Alkalinity, $\mathrm{SO}_{4}, \mathrm{NO}_{3}, \mathrm{Mg}, \mathrm{Ca}$, and $\mathrm{TH}$ were $31.68 \mathrm{mg} / \mathrm{L}^{-1}, 22.77 \mathrm{mg} / \mathrm{L}^{-1}$, and $25.0477 \mathrm{mg} / \mathrm{L}^{-1}$, respectively. Electrical conductivity ranged between 27.19 and $87.30 \mathrm{NScm}^{1-}$ 
TABLE 4: Microbial Load of Borehole Water in the Study Area

\begin{tabular}{|c|c|c|c|c|c|c|c|}
\hline $\begin{array}{l}\text { Coordinate } \\
\text { Easting }\end{array}$ & $\begin{array}{l}\text { Coordinate } \\
\text { Northing }\end{array}$ & $\begin{array}{l}\text { Sampl } \\
\text { e code }\end{array}$ & $\begin{array}{l}\text { Vol. } \\
\text { Wat } \\
(\mathbf{1 0 0 r}\end{array}$ & $\begin{array}{c}\text { Total } \\
\text { Viable } \\
\text { plate count } \\
\text { (cfu/100ml) }\end{array}$ & $\begin{array}{c}\text { Total. } \\
\text { Colform } \\
\text { bacteria } \\
\text { (cfu } / 100 \mathrm{ml})\end{array}$ & $\begin{array}{c}\text { Faecal (E- } \\
\text { coli) } \\
(\mathrm{cfu} / \mathbf{1 0 0 \mathrm { ml } )}\end{array}$ & $\begin{array}{c}\text { WHO } \\
\text { standard } \\
\text { (cfu/100ml) }\end{array}$ \\
\hline 379412 & 519959 & $\mathrm{WS}_{1}$ & $10 c$ & 2700 & 131 & 18 & 0 \\
\hline 379911 & 520013 & $\mathrm{WS}_{2}$ & $10 c$ & 1800 & 122 & 9 & 0 \\
\hline 379830 & 518114 & $\mathrm{WS}_{3}$ & $10 c$ & 70 & 18 & 7 & 0 \\
\hline 379529 & 517932 & $\mathrm{WS}_{4}$ & $10 c$ & 2200 & 127 & 12 & 0 \\
\hline 378788 & 518640 & $\mathrm{WS}_{5}$ & $10 c$ & 0 & 0 & 0 & 0 \\
\hline 378617 & 518550 & $\mathrm{WS}_{6}$ & $10 c$ & 1900 & 12 & 1 & 0 \\
\hline 378254 & 517953 & $\mathrm{WS}_{7}$ & $10 c$ & 2400 & 125 & 13 & 0 \\
\hline 378382 & 517264 & $\mathrm{WS}_{8}$ & $10 c$ & 800 & 15 & 12 & 0 \\
\hline 378752 & 517059 & $\mathrm{WS}_{9}$ & $10 c$ & 3100 & 129 & 14 & 0 \\
\hline 381243 & 514745 & $\mathrm{WS}_{10}$ & $10 c$ & 0 & 0 & 0 & 0 \\
\hline 381030 & 515046 & $\mathrm{WS}_{11}$ & $10 c$ & 2100 & 126 & 1 & 0 \\
\hline 379993 & 513747 & $\mathrm{WS}_{12}$ & $10 c$ & 120 & 19 & 5 & 0 \\
\hline 383419 & 516967 & $\mathrm{WS}_{13}$ & $10 c$ & 2000 & 110 & 8 & 0 \\
\hline 383274 & 516850 & $\mathrm{WS}_{14}$ & $10 c$ & 100 & 157 & 9 & 0 \\
\hline 383482 & 516368 & $\mathrm{WS}_{15}$ & $10 c$ & 1600 & 28 & 5 & 0 \\
\hline 383273 & 516533 & $\mathrm{WS}_{16}$ & $10 c$ & 500 & 12 & 4 & 0 \\
\hline 382971 & 515267 & $\mathrm{WS}_{17}$ & $10 c$ & 4300 & 183 & 27 & 0 \\
\hline 384258 & 513528 & $\mathrm{WS}_{18}$ & $10 c$ & 20 & 11 & 5 & 0 \\
\hline 386097 & 512584 & $\mathrm{WS}_{19}$ & $10 c$ & 800 & 16 & 7 & 0 \\
\hline 386247 & 512325 & $\mathrm{WS}_{20}$ & $10 c$ & 0 & 0 & 0 & 0 \\
\hline 383732 & 509583 & $\mathrm{WS}_{21}$ & $10 c$ & 900 & 198 & 32 & 0 \\
\hline 384175 & 509692 & $\mathrm{WS}_{22}$ & $10 c$ & 0 & 0 & 0 & 0 \\
\hline
\end{tabular}

N/B: $\mathbf{c f u} / \mathbf{m l}=$ Colony forming unit per millimeter

\section{Source: Authors' Analysis}

The results of microbial analyses of borehole water in the study area indicate a high volume of bacteria content in the samples. Specific bacterial organisms observed in the borehole water were coliform count and E.coli. The total coliform bacteria range between 11.00 to $198 \mathrm{cfu} / 100 \mathrm{ml}$, E.coli present in the water sample range between 1.00 and $32.00 \mathrm{cfu} / 100 \mathrm{ml}$, while the total viable count range between 20.00 and $4300 \mathrm{cful} 100 \mathrm{ml}$. Though there was a high

Variability in the amount of microbial load among the sample; results show that only 4 representing 18 percent of total sampled borehole water were found to be satisfactory, (having zero amount of microbial load) in line with WHO standards. More than 80 percent of samples were found to be unsatisfactory in terms of bacteriological quality of the water.

The high point of this study was to link the quality of sample borehole water in the study area to their relative location to septic tank. The next section of this paper addresses the above issue adequately.

\subsection{Relationship between Location of Septic Tank and Quality of Borehole Water}

Table 5 and 6 display the results of Correlation/Regression analyses conducted to examine the relationship between the location of septic tank and water quality parameters. The essence is to empirically ascertain the locational effects of septic tank on borehole water quality in the area. 
TABLE 5: Relationship between Location of Septic Tank (Distance) and Physiochemical Parameter of Borehole Water.

\begin{tabular}{ccccc}
\hline Physiochemical Parameter & $\mathbf{N}$ & $\mathbf{R}$ & Sig. & Remark \\
\hline Colour & 22 & 0.0 & 0.56 & NS \\
Temperature & 22 & 0.17 & 0.33 & NS \\
Turbidity & 22 & -0.03 & 0.87 & NS \\
Dissolved Oxygen & 22 & 0.19 & 0.26 & NS \\
PH & 22 & 0.05 & 0.76 & NS \\
Electrical Conductivity & 22 & -0.15 & 0.39 & NS \\
Total Dissolved Solid & 22 & -0.13 & 0.44 & NS \\
Sodium & 22 & 0.22 & 0.20 & NS \\
Potassium & 22 & 0.19 & 0.26 & NS \\
Chloride & 22 & -0.17 & 0.30 & NS \\
Nitrate & 22 & 0.04 & 0.83 & NS \\
Sulphate & 22 & -0.01 & 0.95 & NS \\
Alkalinity & 22 & 0.13 & 0.44 & NS \\
Total Hardness & 22 & 0.08 & 0.62 & NS \\
Calcium & 22 & 0.08 & 0.66 & 0.38 \\
Magnesium & 22 & 0.15 & & \\
\hline
\end{tabular}

\section{N/B: NS= not significantly related ()}

\section{Source: Authors' Analyses}

Data in table 5 show clearly that relative location of septic tank to borehole water has no significant relationship with the physico-chemical properties of water in the study area. The correlation co-efficient obtained for each parameter were far below 0.50 with value higher than 0.05 . However, the situation was different as data in table 6 indicate that the correlation co-efficient (r) for the three bacteriological variables were significantly related with septic tank location ().

TABLE6:Relationship between Location of Septic Tank and Bacteriological Parameter of Borehole Water.

\begin{tabular}{ccccc}
\hline Parameter & $\begin{array}{c}\text { Regression co- } \\
\text { efficient }\end{array}$ & $\begin{array}{c}\text { Correlation co- } \\
\text { efficient }(\mathbf{r})\end{array}$ & $\begin{array}{c}\text { r-square } \\
\left(\mathbf{r}^{\mathbf{2}}\right)\end{array}$ & Sig \\
\hline Total viable count & -94.23 & -0.437 & 0.191 & $0.007^{*}$ \\
Total Coliform & -4.44 & -0.392 & 0.154 & $0.016^{*}$ \\
Coliform Bacteria & -0.576 & -0.372 & 0.138 & $0.023^{*}$ \\
\hline
\end{tabular}

\section{Correlation is significant at $\mathbf{0 . 0 5}$}

Source: Authors' Analyses

Base on the above data, it is concluded that microbial count decreases with increasing distance of septic tank from the borehole water points. The significant relationship between septic location and microbial load in borehole water suggests that the regression co-efficient for the three indicators of microbial count can be used to predict and control the levels of borehole water contamination as a unit increase in distance (septic location) is likely to yield 4 units decrease in total viable plate count $(B=-94.23 ;), 4$ units in total coliform and a unit in faecal coliform. This prediction is further strengthened by the fact that distance (location of septic tank) accounted for over 19 percent of variation in total viable plate count, 15 percent in total coliform and 12 percent in faecal coliform.

\section{DISCUSSION OF FINDINGS}

The location of sanitary facilities, particularly the septic tank, (also called soakaway pit) and borehole water points are matters of municipal regulations. In Nigeria, such regulations are enacted in line with international standards such as the WHO Health Guidelines and enforced by The states Ministry of Environment/ City Planning Authorities. However, finding in this study indicates that these regulations only exist on paper as the authorities concerned and failed to enforce compliance. In the study area, as revealed in this study, more than 60 percent of septic tanks and borehole water points were located without recourse to the existing regulations. The chi-square test of 'goodness of fit' clearly showed significant deviation of actual location of these sanitary facilities from the expected standards. The indiscriminate siting of sanitary facilities in (septic tanks)

Urban residential areas as witnessed in the study area have weighty repercussions for the health of the population (WHO, 2006). This study has proven that proximity of septic

tank to borehole water could be hazardous to the quality of underground water and by extension the health 
of consumers of such water. Significant evidence abounds from the study linking the amount of microbial loads to relative location of septic tank in the area. The three bacteriological organisms- total coliform, faecal coliform and E-coli found in water samples drawn from these boreholes are the main contaminant of borehole water whose source are likely discharge from the soakaway pit. These findings are not in isolation, as previous studies by Bande, Mbewe, Nzala and Halunda (2014) affirmed that improper alignment of septic tank with borehole water were responsible for 33 percent of heavily contaminated groundwater reserve in parts of Lusaka, Zambia. However, other studies such as Victoria and Ismail (2011); Ochuko and Thaddeus, (2013) found direct association between proximity of septic tank and population of borehole water. Perhaps, explanation for this phenomenon can be obtained from Cornwall, Mullenga and Grana (2010) who posited that locating septic tank close to borehole water enhance the contact time between groundwater and predatory micro-organism that are present in the soils around soakways with resultant effect of contamination of ground water with bacteria that could be of human faecal origin.

In Nigeria, population health is being threatened by water borne diseases particularly typhoid fever and cholera in spite of effort at improving health standards. This is so because; majority of households consumes water from borehole sources without proper treatment and disinfection. Nigeria therefore, is siting on the edge of an impending water related epidemic except effort is made to check improper siting of sanitary facilities. In some parts of Nigeria according to Anaele (2014), pit latrines and open drainage facilities are also located indiscriminately close to domestic water sources. The amount of sampled borehole water proven to be unsatisfactory (over 80 percent) and unsafe for human consumption implies that for the study area alone, more than 60 percent of households are at risk of contracting water borne disease such as dysentery, cholera, typhoid and other diarrhoeal diseases.

\section{CONCLUSION AND RECOMMENDATIONS}

The improper location of sanitary facilities in Nigeria living spaces is by far one of the manifestations of weak regulatory framework evidenced in most developing countries. The declaration of a "state of Emergency" in the water and sanitation sector by national and international institutions is not enough to tackle the menace if such emergency intervention fails to sensitize and inform the people on the need to appropriately locate and manage sanitary facilities. Aside from the septic tank and borehole water, the location of sanitary facilities such as dump sites and waste receptacles need to be highly regulated by relevant authorities to guarantee the health of the population.

In line with the findings of this paper, the following measures are hereby set out as panacea to the menace of improper location of sanitary facilities in Nigeria urban space.

i. Stakeholders in the ministry of Environment, Land/Urban Planning must carry out rigorous sensitization and enlightenment campaigns on the health implications of improper sitting of sanitary facilities in residential areas.

ii. Regular monitoring by relevant agencies must be conducted to enforce compliance with location standard for sanitary facilities.

iii. The proliferation of boreholes in developing countries is largely due to failure OF municipal water supply systems. Municipal Authorities can discourage private boreholes by guaranteeing regular supply of municipal water.

iv. To curb impending epidemic arising out the consumption of contaminated borehole water, disinfectant and proper treatment of domestic water should be encouraged.

\section{REFERENCES}

Abubakar, R. (2017). Access to sanitation facilities among Nigeria Household Determinants and sustainability implications Sustainability,9,547; Doi: 103390/su 9040547

Akoteyon, I. (2015). Evaluating the effect of Septic tank on shallow well in Iba housing estate, Ojo L.G.A, Lagos, Research Journal of watera(1): 78-88

Arwengo, B., Wassawa, M., Nyeko, M. and Kasozi, G. (2017).African Journal Of Environmental Science and Technology (1): 11-18; Doi: 10.5897/AJEST 2016.2216

Banda, 1., Mbewe, A, Nzala, S. and Halwindi, H. (2014). Effect of siting Boreholes and Septic Tanks on Groundwater Quality in St.Bonaventure Township ofLusaka District, Zambia, international Journal of Environmental Science and Toxicology Research,2 (9): 191-198

Etim E. (2016). Assessment of the effect of location of septic tank on borehole Water Quality in Eket L.G.A, Nigeria, unpublished MURP dissertation in The Dept of Urban and Regional planning, University of Uyo, Uyo, Nigeria.

Igbinovia, O., Agwu, E. and Atuanya, E. (2016). Epidemic Potentials of Septic tank sewage systems in Benincity, Edo State, Nigeria, Special Bacteria Pathogens Journal, 2 (1): 1-6

Kawanga, C.O (2003). The impact of urbanization on sanitary Conveyances And Sewage treatmentFacilities in 
the city of Lusaka, Zambia, central Statistical office, Lusaka

Ladan, S.I. (2014). Assessment of sewage Disposal Methods and Environmental Health impacts in Kastina Metropolis,

Northern Nigeria, Journal of Life Science and Technologies 2 (1): 38-43.

Longe,E. (2011). Groundwater resources potential in the coustal resources Sands acquifers, Lagos, Nigeria, Research Journal of Environmental and Earth Science, 3(1): 1-7

Ochuko, U. and Thaddeus.O. (2013). Effect of underground onsite sewage Disposal system on the Quality of water from hand dry well in the Urban Centre of Ughelli, Delta State, Nigeria, Standard Journal of Education and Essay 1(6): 81-90

Odey, E. Zifu, L., Ikhumhen, H, Kalakodo, L., Enang, E., and Giwa, A (2016). an Approach on Environmental Sanitation Situation Andtoilets Septic Tank Design in Urban Nigeria: A case study of Calabar South, International Journal of Waste Resources, 6(3): 1-8

Oluwasola, E., Okunade, O and Adesina, K (2017). Impact of the proximity Of Septic tank on the Bacteriological Quality of Well water from Private Households in Ado Ekiti, Nigeria, Archives of current Research International, 9(4): 1-8

Victoria, O and Ismail, A (2011). Groundwater contamination in Agbowo Community, Ibadan, Nigeria: impact of septic tanks Distances to Well, Malaysian Journal of Microbiology7(3): 159-166

World Health Organization (2006).Water Quality: Gundelence, Standards and Health, London: 1 WA Publishing

World Health Organization (2006).Protecting Groundwater For Health: Managing the Quality of Drinking water source London: 1WA Publishing

Krantz, D. and Kifferstein, B. (2005). Water pollution and Society, Environmental law practice, 4 (1): 1-12 